\title{
Research on the Impact of Financial Structure Optimization on Zhanjiang's Economic Growth
}

\author{
Wenjie Yang, ${ }^{1,}$, Li Sun ${ }^{2}$ \\ ${ }^{1}$ School of Business, Guangdong Coastal Economic Belt Development Research Center of Lingnan Normal University, Zhanjiang, China \\ ${ }^{2}$ School of Economic and Management, Guangdong University of Petrochemical Technology, Maoming, China
}

Email address:

842841395@qq.com (Wenjie Yang),sgyjg@163.com (Li Sun)

${ }^{*}$ Corresponding author

\section{To cite this article:}

Wenjie Yang, Li Sun. Research on the Impact of Financial Structure Optimization on Zhanjiang's Economic Growth. International Journal of Finance and Banking Research. Vol. 6, No. 1, 2020, pp. 11-16. doi: 10.11648/j.ijfbr.20200601.12

Received: February 24, 2020; Accepted: March 9, 2020; Published: March 18, 2020

\begin{abstract}
China is in the period of important strategic opportunities of the "new normal". The "new normal" has brought new development and opportunities to China, and its economic growth has become more stable and its growth momentum has been more diverse. However, at the same time, it also faces problems such as overcapacity, high debt, and gradual weakening of the "demographic dividend". Therefore, economic transformation and adjustment and improvement of the financial structure have become important issues for regional economic development. With Zhanjiang as a sub-central city, Zhanjiang has a huge development opportunity. However, Zhanjiang's financial penetration into the economy is not strong, compared with other cities, Zhanjiang's financial deepening level is relatively low. Therefore this study analyzes the causal relationship between Zhanjiang's bank-led financial structure and economic growth, and explores the key elements of economic growth. Optimize the financial structure and increase the balance and inclusiveness of development. Give full play to the role of market mechanisms to further release market vitality. Scientifically regulate and control risks to realize Zhanjiang's economic transformation and upgrading and sustainable economic development under the "new normal". Empirical analysis shows that FIR and FI are Granger causality of GDP and have a negative impact. There is no Granger causality between DLR, ER and GDP, which has a positive impact.
\end{abstract}

Keywords: Financial Development, Financial Interrelations Ratio, Economic Growth

\section{Introduction}

Financial structure theory is one of the earliest and most influential theories on the study of financial development. Its founder and main representative is Goldsmith, a professor at Yale University. Goldsmith put forward a series of indicators to measure the financial structure, in order to show the inherent laws of financial structure change. The most important indicator is (Financial interrelations ratio) FIR, which is the ratio of existing financial assets to national wealth.

Financial structure reflects the various markets that realize the mobilization and transfer of financial resources. The financial structure reflects the relative scale and status of various markets, various institutions, and trading instruments in the entire financial system and the role they play in economic growth.
The optimization of the financial structure will help increase reserves, improve service functions and risk control capabilities, and promote economic growth through effective resource allocation, increase investment levels, enhance basic financial functions, improve the efficiency of financial operations, and meet the increasing variety of Financial needs are conducive to improving the quality of people's economic life and increasing overall social welfare.

China is in the period of important strategic opportunities of the "new normal". The "new normal" has brought new development and opportunities to China, and its economic growth has become more stable and its growth momentum has been more diverse. But at the same time. However, at the same time, it also faces problems such as overcapacity, high debt, and gradual weakening of the "demographic dividend". Therefore, economic transformation and adjustment and improvement of the financial structure have become important issues for regional economic development. 
With Zhanjiang as a sub-central city, Zhanjiang has a huge development opportunity. However, Zhanjiang's financial penetration into the economy is not strong, compared with other cities, Zhanjiang's financial deepening level is relatively low. Zhanjiang's Financial interrelations ratio gradually decreased from 0.725 in 2000 to 0.442 in 2006 , and then rose to 0.665 in 2017 . This shows that credit support for Zhanjiang's economic growth is weak and the economic allocation of financial resources is inefficient. Therefore this study analyzes the causal relationship between Zhanjiang's bank-led financial structure and economic growth, and explores the key elements of economic growth. Optimize the financial structure and increase the balance and inclusiveness of development. Give full play to the role of market mechanisms to further release market vitality. Scientifically regulate and control risks to realize Zhanjiang's economic transformation and upgrading and sustainable economic development under the "new normal". The Financial interrelations ratio of cities in Guangdong Province in the past 5 years are shown in Table 1:

Table 1. Financial interrelations ratio of cities in Guangdong in the past 5 years.

\begin{tabular}{llllll}
\hline city & $\mathbf{2 0 1 4}$ & $\mathbf{2 0 1 5}$ & $\mathbf{2 0 1 6}$ & $\mathbf{2 0 1 7}$ & $\mathbf{2 0 1 8}$ \\
\hline Guangzhou & 1.450 & 1.508 & 1.477 & 1.514 & 1.739 \\
Shenzhen & 1.416 & 1.853 & 1.804 & 1.775 & 1.941 \\
Shaoguan & 0.602 & 0.636 & 0.634 & 0.690 & 0.711 \\
Zhuhai & 1.299 & 1.412 & 1.758 & 1.737 & 1.797 \\
Shantou & 0.625 & 0.641 & 0.626 & 0.646 & 0.778 \\
Foshan & 1.021 & 0.993 & 0.986 & 0.965 & 1.052 \\
Jiangmen & 0.902 & 0.990 & 0.978 & 1.011 & 1.082 \\
Zhanjiang & 0.598 & 0.653 & 0.630 & 0.661 & 0.719 \\
Maoming & 0.318 & 0.351 & 0.381 & 0.390 & 0.428 \\
Zhaoqing & 0.635 & 0.650 & 0.615 & 0.707 & 0.829 \\
Huizhou & 0.725 & 0.784 & 0.924 & 0.991 & 1.190 \\
Meizhou & 0.717 & 0.767 & 0.793 & 0.913 & 1.055 \\
Shanwei & 0.376 & 0.401 & 0.422 & 0.473 & 0.462 \\
Heyuan & 0.909 & 0.988 & 0.988 & 1.073 & 1.147 \\
Yangjiang & 0.594 & 0.599 & 0.649 & 0.709 & 0.745 \\
Qingyuan & 0.785 & 0.830 & 0.819 & 0.919 & 0.996 \\
Dongguan & 0.945 & 0.953 & 0.937 & 0.896 & 0.991 \\
Zhongshan & 0.868 & 0.925 & 1.051 & 1.031 & 1.111 \\
Chaozhou & 0.420 & 0.405 & 0.377 & 0.392 & 0.391 \\
Jieyang & 0.486 & 0.489 & 0.494 & 0.525 & 0.536 \\
Yunfu & 0.803 & 0.838 & 0.834 & 0.903 & 0.933 \\
\hline
\end{tabular}

\section{Research Theory}

Goldsmith (1969) [1] believed that the development of the banking system was the beginning of modern financial development and economic growth. Financial development has gone through three stages. Banks have played different roles: In the initial stage of financial industry development, banks played an important role in the financial system. In the second stage, the government and government financial institutions played a greater role, but banks still dominated the financial system, which reflected the hybrid characteristics and the emergence of large joint-stock companies. In the third stage. Due to the rapid economic development and the optimization of the industrial structure, the superiority of the capital market is further highlighted, and financial institutions are diversifying, leading to the decline of the status of banks and the rise of the status of savings institutions and private and public insurance organizations.

This shows that in the financial system, banks have more significant advantages in the initial stage of economic growth. A sound banking system can make it easier for companies to obtain long-term bank loans and external financing. The bank-led financial system converts savings into investments and allocates resources, so capital can rapidly expand and accumulate.

Many scholars believe that the Japanese bank-led system is a key factor in achieving rapid economic growth in Japan, and is a successful case of bank-led financial structures. Japan was the first of its kind in East Asia to achieve economic growth, and its economic growth and financial development model has been largely emulated by other East Asian countries. However, since the Asian financial crisis in 1997, Japan's economic and financial structure has faced a huge crisis, and its economic growth and financial development model has also begun to transform and change.

Therefore, whether it is studying Japan 's economic miracle or economic crisis, it will deepen the understanding of East Asia 's special economic and financial operating models, help to summarize the inherent rationality and disadvantages of the East Asian model, and make recommendations for the reform of China's financial system.

Levine (2002) [2] believes that banks are conducive to economic growth and the development of overall finance. The bank basic theory explains that commercial banks play an important role in economic development through resource optimization and risk reduction. Beck and Levine (2002) [3] argued that in a liquid market, investors can sell their stocks cheaply; therefore, management and supervision receive fewer rewards. An effective market reduces individuals' research on companies because individuals have so little information that it is difficult to make a timely response before the stock price becomes public. The bank basic infrastructure can alleviate this problem, as banks have less public information.

Thangavelu and Ang (2004) [4] explored the dynamic relationship between financial development and economic growth in Australia using co-integration and causal analysis of VAR models of time series data under a bank basic financial structure. The results show that: 1 . There is a two-way causal relationship between bank-based financial development and economic growth. 2. The interest rate factor in the research model does not affect the empirical results.

Nousheen and Bhutta (2014) [5] believe that the bank-based theory explains that commercial banks play an important role in economic development through resource optimization and risk reduction.

Shun-Ho CHU (2016) [6] believes that the bank-based financial structure emphasizes the positive role played by banks: (1) access to information of enterprises and managers to improve fund allocation and corporate governance; (2) manage liquidity risks to Strengthen investment efficiency and economic growth; (3) Mobilize funds to return economies of scale. 
Demir and Hall (2017) [7]attempted to analyze the impact of the country's financial structure on economic growth from a new structuralist perspective. Among them, the bank basic theory believes that the banking system emphasizes the positive impact of banks on the economy through three main channels. First, banks obtain information about managers and companies to improve corporate governance efficiency and improve capital allocation. Second, banks manage intertemporal, cross-sectoral and liquidity risks, thereby improving investment efficiency and promoting economic growth. Finally, banks provide funding to benefit from economies of scale.

\section{Methodology}

\subsection{Data}

The data for this study were obtained from the Guangdong Bureau of Statistics and the Zhanjiang Statistical Yearbook. The research object is financial institutions in Zhanjiang. The research sample is from 2000 to 2018, with each year's data as the research interval.

\subsection{Research Design}

\subsubsection{Dependent Variable}

GDP growth rate (GDP)

The GDP growth rate can truly reflect the changes in the national economy, and provides important tools and basis for the national and regional economic development strategic goals and macroeconomic policies. At the same time, the statistics of GDP growth rate is relatively easy. It has the advantages of accurate statistical data and less repeated calculations. As a total indicator, it is closely related to the two major macroeconomic indicators of inflation and unemployment. The most basic of the three major indicators for formulating macro-control policies.

The economic scale of a country is one of the important signs of its economic strength and international status. Therefore, many scholars choose the actual GDP growth rate as an indicator of economic growth: Samargandi, Fidrmuc and Ghosh (2014) [8] study the impact of financial development in Saudi Arabia on the economy; Madichie, Maduka, Oguanobi and Ekesiobi (2014) [9] study the relationship between financial development and economic growth in Nigeria; Adeniyi, Oyinlola, Omisakin and Egwaikhide (2015) [10] Measure the impact of financial reforms on Nigeria's economic growth; Ductor and Grechyna (2015) [11] explores studies on the interdependence between financial development and real sector output and the impact on economic growth.

The calculation formula is expressed as follows:

$$
\text { GDP growth rate= }
$$

(current GDP-previous GDP) / previous GDP* 100\%

\subsubsection{Independent Variable}

(1) Financial interrelations ratio (FIR)

Financial instruments are increasingly developed and constantly innovated. In order to clarify how financial institutions, financial transaction flows, and financial instrument stocks interact to form and promote financial development, Goldsmith (1969) [1] finds out the major economic influencing factors, namely Financial interrelations ratio.

Financial interrelations ratio is seen as a fundamental feature of financial development. The change in Financial interrelations ratio reflects the changing relationship between the financial superstructure and the economic infrastructure. It is also one of the most important indicators reflecting the status and role of a country's financial structure in its national economy. The more developed the financial system, the higher the financial interrelations ratio. However, the increase of a country's Financial interrelations ratio has a "ceiling". It will be limited by a certain height and development stage, and the Financial interrelations ratio will tend to stabilize, especially When the Financial interrelations ratio reaches the range of 1-1.5. Therefore, many scholars choose financial interrelations ratio as indicators of financial development:

Khan and Qayyum (2005) [12] studied the relationship between energy consumption, economic growth, trade and financial development in South Asia. Use bank private sector loans / GDP as financial interrelations ratio. It is found empirically that financial development is positively related to economic development, and that there is a one-way causal relationship between financial development and economic growth.

Adnan (2011) [13] believes that financial development can be measured by financial interrelations ratio. Research shows that a strong financial system can diversify risks and promote efficient capital allocation. The higher the degree of financial development, the more able to mobilize savings and allocate to higher returns.

Boukhatem (2016) [14] used data from 67 low- and middle-income countries from 1986 to 2012 to explore the impact of financial development on poverty. Empirical findings show that financial interrelations ratio have a negative correlation with poverty indicators and can effectively eliminate poverty.

The calculation formula is expressed as follows:

Financial interrelations ratio=bank loans / GDP

\section{(2) Loan-deposit Ratio (LDR)}

The loan-deposit ratio is one of the important indicators used by commercial banks to measure bank liquidity risk. From the perspective of bank profitability, the higher the loan-to-deposit ratio, the better, because deposits are subject to interest payments, which is the so-called cost of funds. If a bank has a lot of deposits and few loans, it means that it has high costs and low income, The bank's profitability is poor. Because the commercial bank is for profit, it will try to increase the loan-deposit ratio. From the perspective of banks' resistance to risks, the loan-deposit ratio should not be too high, because banks also have to deal with the daily cash withdrawals and daily settlements of customers. It is necessary for banks to maintain a certain reserve of cash deposits. This part of the funds will be insufficient, which will cause the bank's payment crisis. If the payment crisis spreads, it may lead to a financial crisis, which will greatly harm the regional or national economy. Many scholars choose the loan-deposit 
ratio as an indicator to measure bank liquidity risk:

Ming F, Yunfeng L (2017) [15] Based on data from 103 banks in China, using the net financing stability ratio and the loan-deposit ratio as a measure of bank structure liquidity. Studies have shown that increasing the proportion of deposits is essential for banks' liquidity.

Minghui L, Bian Z (2018) [16] used the relevant data from 2000 to 2014 to analyze whether the net stable financing ratio can replace the loan-deposit ratio as a liquidity risk monitoring indicator from the overall and local dimensions. Empirical analysis shows that the loan-deposit ratio is an important regulatory indicator of liquidity risk.

The calculation formula is expressed as follows:

$$
\text { Loan-deposit Ratio=bank loan / bank deposit }
$$

\subsubsection{Control Variable}

(1) Total Investment in Fixed Assets (TIF)

The total investment in fixed assets is the workload of construction and purchase of fixed assets in terms of currency. It is a comprehensive indicator that reflects the scale, speed, proportional relationship and use direction of fixed asset investment. Total Investment in Fixed Assets includes investment in capital construction, investment in renovation and renovation, investment in fixed assets in state-owned units, investment in real estate, investment in collective fixed assets in urban areas, joint ventures, joint-stock economies, foreign-invested economies, Hong Kong, Macao, and Taiwan invest in economic and other types of fixed asset investment, rural collective fixed asset investment of more than 50,000 yuan, private housing investment in urban industrial and mining areas and national defense infrastructure investment.

The calculation formula is expressed as follows:

Total Investment in Fixed Assets=Social Fixed Assets Investment / GDP

(2) Employment rate (ER)

Employment rate refers to the proportion of the employed population to the economically active population (employed population + unemployed population) at a certain point in time, and is usually expressed as a percentage. In general, during the period of economic prosperity, the unemployment rate is low and the level of employment is high. During the period of economic depression, the level of employment is low and the unemployment rate is high. It can be seen that the increase and decrease in the level of national output will directly affect the increase or decrease in the employment rate.

The calculation formula is expressed as follows:

Employment rate=number of employed persons /employed population +unemployed population

\section{Empirical Results}

\subsection{Time Series Diagram}

Before performing the ADF unit root test, we need to determine the form of the test regression model. The inspection can be judged by the time series diagram of the sequence drawn by EVIEWS. There are three forms of regression, namely: 1 . None Lag length, means no intercept and no time series; 2. Intercept, means Including intercepts without time trend, the series deviates from zero, but there is no obvious time trend; 3 . trend and intercept, Used for sequences containing intercept terms and time trends, where the sequence moves significantly in one direction over time.

According to EVIEWS, a time series diagram of each variable is drawn: the series GDP, FIR, LDR, TIF, and ER contain trend and intercept. The time series diagram is as follows:

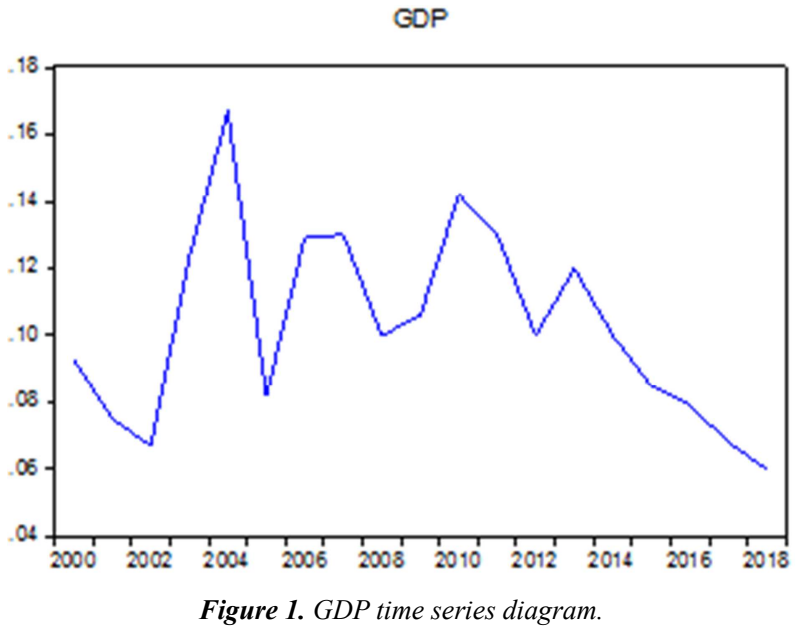

FR

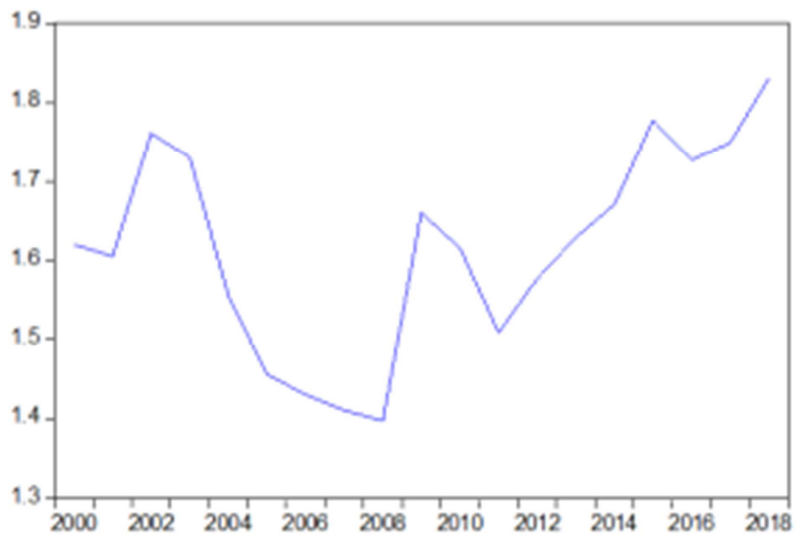

Figure 2. FIR time series diagram.

LDR

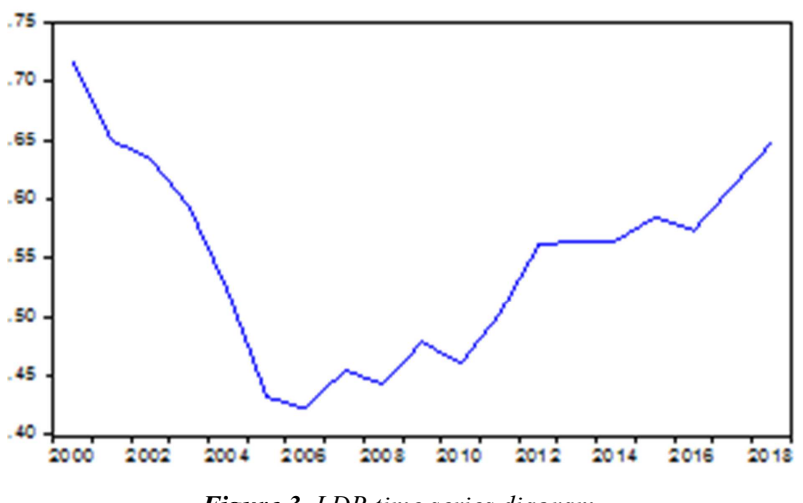

Figure 3. LDR time series diagram. 
TIF

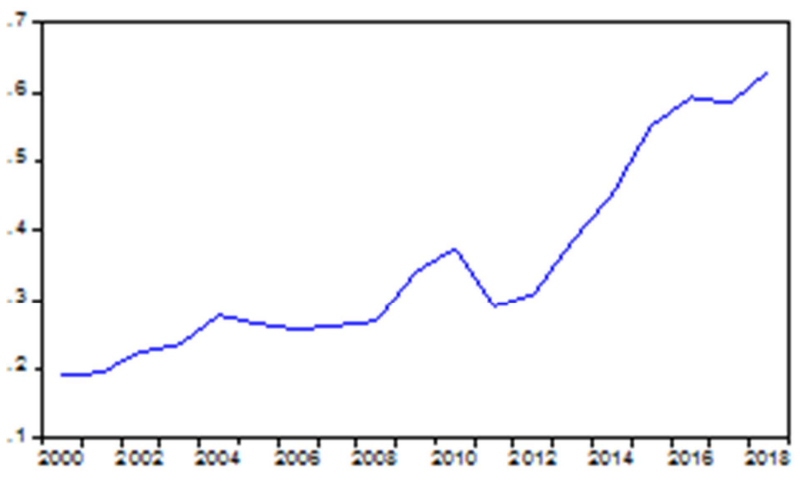

Figure 4. TIF time series diagram.

ER

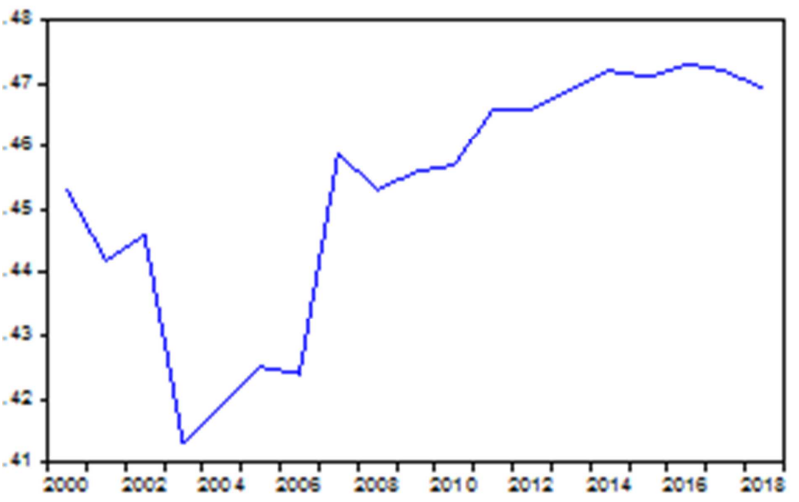

Figure 5. ER time series diagram.

\subsection{Unit Root Test}

According to the change of the timing diagram of the variable, The Unit Root Test is set to select both the trend and intercept method. The verification results are shown in Table 2:

In the Unit Root Test of GDP in the original sequence, the $\mathrm{T}$ statistic probability is 0.222 , which is greater than 0.1 , so the original sequence is not stable. After the first order difference, the probability of the $\mathrm{T}$ statistic is 0.000 , which is less than 0.01, so GDP is stable after the first order difference.

In the Unit Root Test of FIR in the original sequence, the T statistic probability is 0.737 , which is greater than 0.1 , so the original sequence is not stable. After the first order difference, the probability of the $\mathrm{T}$ statistic is 0.046 , which is less than 0.05 , so FIR is stable after the first order difference.

In the Unit Root Test of LDR in the original sequence, the $\mathrm{T}$ statistic probability is 0.621 , which is greater than 0.1 , so the original sequence is not stable. After the first order difference, the probability of the $\mathrm{T}$ statistic is 0.097 , which is less than 0.1, so LDR is stable after the first order difference.

In the Unit Root Test of FIT in the original sequence, the $\mathrm{T}$ statistic probability is 0.851 , which is greater than 0.1 , so the original sequence is not stable. After the first order difference, the probability of the $\mathrm{T}$ statistic is 0.018 , which is less than 0.05 , so FIT is stable after the first order difference.

In the Unit Root Test of ER in the original sequence, the $\mathrm{T}$ statistic probability is 0.194 , which is greater than 0.1 , so the original sequence is not stable. After the first order difference, the probability of the T statistic is 0.006 , which is less than 0.01 , so ER is stable after the first order difference.

Table 2. Variable unit root test results table.

\begin{tabular}{lllll}
\hline ADF Test & $\begin{array}{l}\text { Original } \\
\text { sequence }\end{array}$ & Stationarity & $\begin{array}{l}\text { First order } \\
\text { difference }\end{array}$ & Stationarity \\
\hline GDP & 0.222 & unstable & 0.000 & steady \\
FIR & 0.737 & unstable & 0.046 & steady \\
LDR & 0.621 & unstable & 0.097 & steady \\
FIT & 0.851 & unstable & 0.018 & steady \\
ER & 0.194 & unstable & 0.006 & steady \\
\hline
\end{tabular}

\subsection{Johansen Test}

The results of the cointegration model are shown in Table 3. The P-value of At most 4 is 0.847 , which is greater than 0.05, indicating that GDP and FIR, DLR, FI, and ER have long-term stable relationships. The cointegration equation is as follows:

$$
\mathrm{GDP}=-0.893 \mathrm{FIR}+0.637 \mathrm{DLR}-0.039 \mathrm{FI}+0.488 \mathrm{ER}
$$

Through the cointegration equation, we can know that in the long-term stable relationship, FIR and GDP have a negative correlation. For every $1 \%$ increase in FIR, GDP decreases by $0.893 \%$. There is a positive correlation between DLR and GDP. For every $1 \%$ increase in DLR, GDP increases by $0.637 \%$. FI has a negative correlation with GDP. For every $1 \%$ increase in FIC, GDP decreases by $0.039 \%$. There is a positive correlation between ER and GDP. For every $1 \%$ increase in ER, REALGDP rises by $0.488 \%$.

Table 3. Johansen Test results table.

\begin{tabular}{lllll}
\hline $\begin{array}{l}\text { Hypothesized } \\
\text { No. of CE (s) }\end{array}$ & Eigenvalue & $\begin{array}{l}\text { Trace } \\
\text { Statistic }\end{array}$ & $\begin{array}{l}\text { 0.05 Critical } \\
\text { Value }\end{array}$ & Prob \\
\hline None * & 0.990 & 176.411 & 69.818 & 0.000 \\
At most 1* & 0.919 & 97.901 & 47.856 & 0.000 \\
At most 2* & 0.871 & 54.993 & 29.797 & 0.000 \\
At most 3* & 0.692 & 20.076 & 15.494 & 0.009 \\
At most 4 & 0.002 & 0.037 & 3.841 & 0.874 \\
\hline
\end{tabular}

\subsection{Granger causality}

Table 4 shows the Granger causality between GDP and FIR, DLR, and FIR. As can be seen from Table 4, FIR and FI are Granger causality of GDP. GDP has no Granger causality with DLR and ER.

Table 4. Granger Causality Table.

\begin{tabular}{lll}
\hline Null Hypothesis: & F-Statistic & Prob. \\
\hline DFIR does not Granger Cause DGDP & 3.959 & 0.047 \\
DGDP does not Granger Cause DFIR & 0.625 & 0.551 \\
DDLR does not Granger Cause DGDP & 0.532 & 0.600 \\
DGDP does not Granger Cause DDLR & 1.723 & 0.219 \\
DFI does not Granger Cause DGDP & 3.959 & 0.047 \\
DGDP does not Granger Cause DFI & 0.625 & 0.551 \\
DER does not Granger Cause DGDP & 2.706 & 0.107 \\
DGDP does not Granger Cause DER & 2.715 & 0.106 \\
\hline
\end{tabular}




\section{Conclusion}

It can be seen from the empirical results that FIR and FIT are Granger causality of GDP, which have a negative impact. There is no Granger causality between LDR, ER and GDP, which has a positive impact. Research shows that banks play an important role in Zhanjiang's financial system, but there are serious financial repression, credit funds cannot be effectively converted into investments, and the financial structure is defective, failing to truly release the vitality of the market.

In response to the financial repression in Zhanjiang, relevant financial institutions need to improve their financial business and change their business models: (1) Reduce the barriers to loans to private enterprises, eliminate financing discrimination against private small and medium-sized enterprises, and improve the level and quality of financial services for private enterprises. (2) Banks need to set up a business sector for the private economy, specifically to train private companies with poor loan application capabilities and at a disadvantage of loan competition. Relying on a professional private enterprise marketing service team, it has effectively improved the efficiency of business marketing, acceptance, approval and risk prevention and control, and improved the professional level of private financial services. Better adapt to the characteristics of private enterprises' operation and financing needs, effectively solve the problem of "difficult financing and expensive financing" for small and micro enterprises, and further increase the support for small and micro enterprises. (3) Actively strengthen cooperation between banks and governments to help private companies improve social credit. The government can take measures such as collecting credit data of private companies, periodically conducting credit rating activities, and establishing a mechanism for credit incentives and penalties.

\section{Acknowledgements}

This paper was supported by 2019 Philosophy and Social Science planning funded project of Zhanjiang City (Grant Number: ZJ19QN03); 2019 Guangdong Coastal Economic Belt Development Research Center of Lingnan Normal University (Grant Number: 20194L02); And Humanities and Social Sciences Research Project of Lingnan Normal University (Grant Number: ZW2026).

\section{References}

[1] Goldsmith, R. W. Financial structure and development [M]. Yale University Press: Britain, 1969.

[2] Levine R. Bank-Based or Market-Based Financial Systems: Which Is Better? [J]. Journal of Financial Intermediation, 2002, 11 (4): 398-428.
[3] Beck, T., \& Levine, R. Industry growth and capital allocation: does having a market- or bank-base system matte? [J]. Journal of Financial Economics, 2002, (64): 174-180.

[4] Thangavelu S M, Jiunn A B, James. Financial development and economic growth in Australia: An empirical analysis [J]. Empirical Economics, 2004, 29 (2): 247-260.

[5] Shah, S. Z. A., \& Bhutta, N. T. Does financial deepening create financial crises? [J]. Journal of Emerging Trends in Economics and Management Sciences, 2014, 5 (7): 115-120.

[6] Shun-Ho CHU. (2106). An Empirical Study on the Impact of Macau's Financial Development on Economic Growth -Analysis of Co-integration and Causality [J]. Macao Economy, (40): 1-12.

[7] Demir, A, D., \& Hall, S, G. Financial structure and economic development: Evidence on the view of "new structuralism". [J] International Review of Financial Analysis, 2017, (52): 252-259.

[8] Samargandi N, Fidrmuc J, Ghosh S. Financial development and economic growth in an oil-rich economy: The case of Saudi Arabia [J]. Economic Modelling, 2014, 43: 267-278

[9] Madichiel, C., Maduka, A., Oguanobi, C., \& Ekesiobi, C. Financial development and economic growth in Nigeria: A reconsideration of empirical evidence. [J]. Journal of Economics and Sustainable Development, 2014, 1 (3): 549-554.

[10] Adeniyi O, Oyinlola A, Omisakin O, et al. Financial development and economic growth in Nigeria: Evidence from threshold modelling [J]. Economic Analysis and Policy, 2015, 47: 11-21.

[11] Ductor, L.., \& Grechyna, D. Financial development, real sector, and economic growth. [J]. International Review of Economics \& Finance, 2015, (37): 393-405.

[12] Khan, M. A., Qayyum, A., Sheikh, S. A., \& Siddique, O. Financial development and economic growth: The Case of Pakistan. [J]. Pakistan Development Review, 2005, 44 (4): 819-837.

[13] Adnan, N. Measurement of Financial Development: A Fresh Approach. Pakistan: University of Surrey, United Kingdom and Comsats Institute of Information Technology. 2011.

[14] Boukhatem J. Assessing the direct effect of financial development on poverty reduction in a panel of low- and middle-income countries [J]. Research in International Business and Finance, 2016, 37: 214-230.

[15] Ming F, Yunfeng L. Empirical Analysis of Influencing Factors of Commercial Banks' Liquidity in China [J]. Journal of Financial Education Research, 2017 (02) 9-18.

[16] Minghui L, Bian Z. Can Basel III Net Stable Financing Ratio Replace the Deposit-to-Loan Ratio? -Empirical Evidence from Chinese Listed Banks [J]. Economics and Trade Forum, 2018, 229 (01): 50-60. 